\title{
Determinants of Effective Inventory Management A Study of Consumer Durable Retailers
}

\author{
Vibhuti Tripathi and Priyanka Kochhar
}

\begin{abstract}
Global retailing is evolving into hi-tech business Indian retail market is poised to follow the path with large number of global players eyeing the market. $10.6 \%$ of growth Indian Retail market has experienced between the year 2010 and 2012. Revolution in Indian Retail has been brought about with the change in demographic profile, increase in income levels, urbanization, technology and globalization. Growth comes along with challenges, which retailers have to manage in order to sustain in the competitive environment. It is imperative for the retailers to offer adequate service levels to sustain. The determinants of service levels for a retailer can be linked to availability and variety which aspects can be maintained through a healthy inventory. The paper attempts to address the objective of identifying determinants of effective inventory management. An exploratory survey was conducted among 60 retailers from Allahabad, Lucknow, and New Delhi dealing with consumer durables. Data was treated with factor analysis and Regression analysis. Four Factors of Retailer Size, Supplier Relationship, Service Level and Demand Uncertainty emerged as the determinants of effective inventory management. Positive relationship emerged between Retailer Size, Supplier Relationship, Demand Uncertainty and Effective Inventory Management through regression analysis.
\end{abstract}

Keywords--- Retailers, Consumer Durables, Inventory Management

\section{INDIAN RETAIL SCENARIO}

$\mathrm{I}_{\mathrm{N}}$ NDIAN retailing is inching towards the growth stage in the business cycle. The Indian retail industry is rising as one of the dynamic industries with the entry of domestic players and international player (Yuvarani, 2009). The current estimated value of Indian retail industry is about USD 500 billion and it is expected to reach to USD 1.3 trillion by 2020 (FICCI, 2012). Indian Retail market showed $10.6 \%$ of growth between 2010 and 2012. Retail industry turned out to be a significant pillar of the Indian economy as it is contributing $22 \%$ to the national GDP and employing $8 \%$ of the total workforce, (IBEF, 2013). The total retail spending is expected to double over the next 5 years and organized retail in India is expected to account for about 21 percent of the total retail expenditure (Deloitte, 2011). The sector is attracting the attention of global retailers/multinationals (Dalwadi et. al., 2010) who believe that the next wave of growth in terms of generating revenues,

Vibhuti Tripathi, Assistant Professor, School of Management Studies, Motilal Nehru National Institute of Technology, Allahabad. E-mail:vibhuti.tripathi@gmail.com

Priyanka Kochhar, Research Scholar, School of Management Studies, Motilal Nehru National Institute of Technology, Allahabad. E-mail:kochhar.p@gmail.com DOI: 10.9756/BIJIEMS.10448 reaching new customer segments, harnessing $R \& D$ and innovative skills will come from developing countries and emerging markets like India, Mongolia, Sri Lanka and Indonesia(ATKearney,2012).The most important development has been the emergence of various retail formats of most of product categories. Being the largest retail segment in 201314 hypermarkets acquired 21 per cent of the total retail space.

Change in Indian Retail industry has been brought about due to change in demographic profile, growing nuclear families, increasing income levels, urbanization, technology upgradation and globalization. Adding to this some of the changes that have affected India's social structure are the increase in nuclear families, aspiring middle class and youth, increasing population of working women \& double income household \& increasing work pressure (Babu, 2012; Bajaj, 2010; Nair, 2009).

Addressing the challenges of the intensely competitive retail environment and demanding customers who look for convenience to make better utility of their time and seek for speed, efficiency, variety, better quality and healthy shopping environment; it is imperative for the retailers to offer adequate service levels to sustain. The determinants of service levels for a retailer can be linked to availability and variety. Both these aspects can be maintained by a retailer by way of maintaining a healthy inventory. This can reduce loss of sales on account of less inventory and become responsive to ever changing and dynamic environment.

Excess inventory consumes retail space, increases financial load and fewer inventories disrupt retail operations (Dimitrios, 2008). Hence inventory is effectively managed to maintain adequate products supply and eliminates duplication in stock ordering. The management of inventory is a vital problem experienced by retailers especially because of handling multiple product categories with unique characteristics. Inventory in retail needs to be managed properly in order to meet the customer requirement, availability issue, profit and cost reduction.

The paper attempts to address the objective of identifying determinants of effective inventory management.

\section{CONSUMER DURABLES}

Retail goods are conventionally divided into Durable goods which are likely to last at least for five years and are purchased as gifts for special occasions or on a seasonal basis (ibs, 2005). Durable goods are various household appliances, audio and video equipment, games, digital cameras, mobiles and other electronic items (Advisen, 2012). And Non Durable goods include food, clothing and other categories that form the bulk of stock across the counter. 


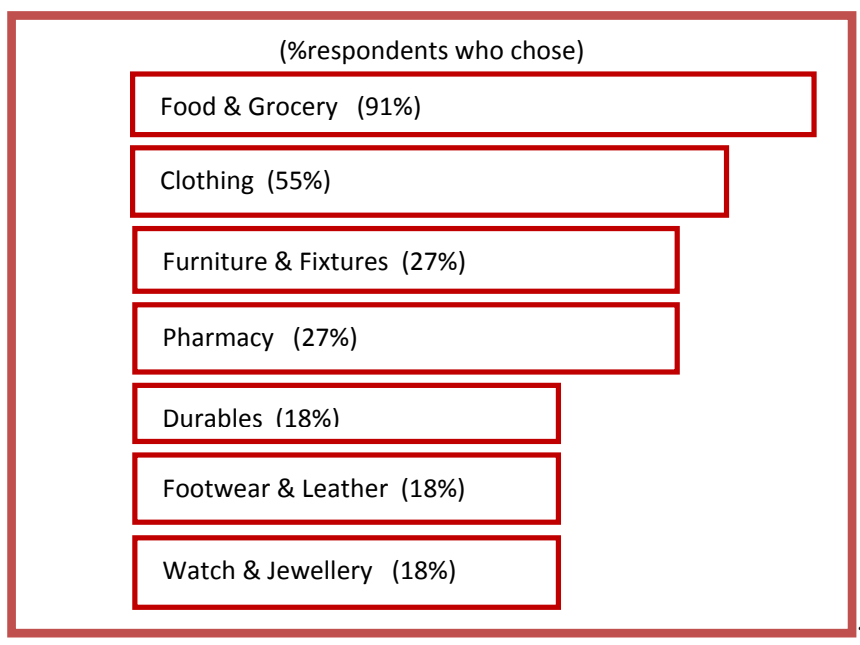

Figure 1: Fastest Growing Retail Segment in India

\section{Source: KPMG Retail Survey}

The chart mentioned above shows the growth of various retail segments. Food \& grocery is the single largest retail category accounting for $\sim 90 \%$ of total retail market. Durables are growing with $18 \%$ of market share. This category is offering maximum value to customers and hence is better able to penetrate more into the market.

Consumer Durables comes in the 4th position showing that in future this segment has potential market. Consumer durable is broadly classified into two, Consumer electronics and Consumer appliance. And consumer appliance is sub-divided into Brown Goods and White Goods. Washing machines, refrigerators and coffee machines are the white goods, DVD players, televisions and stereo are the brown goods (ibs, 2005).

Consumer durable sector in terms of revenue is ranked 7.3 USD billions in FY11 which is up by $15.9 \%$ from FY 10 (ibef, 2012). The sector is estimated to grow at a CAGR of $14.8 \%$ to USD 12.5 billion by 2015 and $100 \%$ FDI under automatic route is allowed in the electronics hardware manufacturing sector making the sector attractive for investment.

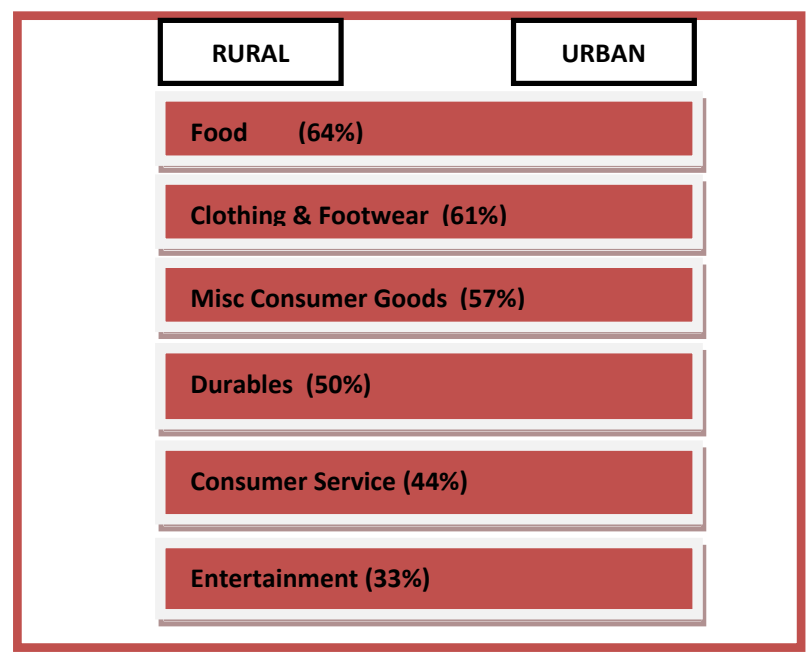

Source: NSSO $5^{\text {th }}$ round: KPG

Figure 2: Share of Market: Urban vs. Rural
Retail market is basically divided into two parts urban and the rural market. Urban markets account for $65 \%$ share of total revenue in India. Refrigerator and televisions in rural market are likely to witness growth in 2013 and compound annual growth rate (CAGR) is expected to grow at $25 \%$ from USD 2.1 billion to USD 6.4 billion by FY 15 (cci, 2013). Analysis done by NSSO in the above chart shows that market share of consumer durable for urban and rural is 50\% each indicating potential of consumer durable in both the market.

From necessities such as household appliances to wants such as the most in -demand technology products, computer and electronics retailers carry a wide array of products that have significantly made lives easier. Increasing demand is brought by younger generations who are becoming dependent on the products that are convenient to use and are equipped with upgraded technology. Demand of consumer durable products depend on several factors such as Global economic factor, Commercialization of consumer durable, Integrated Product and Service management, Seasonal influence on supply, Customer dynamics (ibs, 2005). These factors if not controlled properly create challenges for the retailers.

Intense competition among players, expensive raw material is also creating high pressure on retailers. Competition leads to higher expense and lesser pricing power which have a detrimental effect on the sector. Products are undergoing changes due to consumer demand. These changes help in meeting the consumer demands, transportation and packaging needs to improve time and place utility of product. In one of the study done using enterprise survey data on 1948 stores in 41 large cities of India found key obstacles and problems faced by retailers that are: Inadequate power supply and poor access to finance are the pressuring problems (Amin, 2010). Adding to this increase in Indian costumer demands of more value to money both in terms of quality of durables and convenience of buying has imposed pressure on the retailers (Mishra, 2010).

\section{LITERATURE REVIEW}

Retail industry is facing competition which in turn reducing profit margins. By effectively managing their inventory, retailers can increase their profits, their relationships with the consumers and their competitiveness. Hence retailers have to effectively manage their vital asset that is inventory for reducing costs, stocks and improving the customer experience. The best practices in inventory management call for a balance between inventory and service levels, identifying the importance of stock availability, and accurate inventory data (Wilson, Kingdon and Reeve, 1995).

Growing retailers take inventory management as a tool for improving customer satisfaction through refined merchandise assortments and in-stock positioning. It improves their ability to satisfy key customer demands by placing the right product at the right time. Retail inventory management provides availability at the lowest possible cost (Gill, Soma and Sutherland, 1985; Tersine, 1988; Sherbrooke, 1992). According to Silver, Pyke and Peterson (1998) company's future is dependent on how the company manages the inventory and the cost involved that is the amount invested in 
holding the inventory, transportation, and management of it. Effective inventory management provides guidelines to the retailers in order to satisfy their consumers and maintain maximum profits by right trading of the costs and service levels (Zheng, 2005).Retailers have to manage their inventories of various product categories, keeping the characteristics of products into consideration such as perishability, trends, fashion, staple, etc uniquely. Retail inventory management helps in managing greater variety of products, keeping in mind the space available with them (The Difficult Task of Retail Inventory Management, 2007).

Retail operations are complex as there is different variety of products and each category has large number of brands available. Retailers deal with millions of customers and manage hundreds of transaction daily. Retailers use inventory management as a tool to enhance customer satisfaction through merchandise assortments. Retailers believe that satisfying customer need could help in increasing revenues, lowering the inventory levels, and improving return on investment (Aerrabolu, 2012). Effective inventory management is an area which helps retailers to differentiate themselves and makes them successful. Inventory allows retailers to sell variety of goods, maintain safe levels of items and large stock to spread fixed cost (Singh, 2011). Inadequate merchandise, vacant shelves give a negative impression to the customer regarding the store and they become hesitant to visit the store in future.

Indian market is complex and has heterogeneity in Attributes like Religion, Language, dialect, Value system (Halepete, Iyer Park, 2008), with such diversity demand for product variety. There is $\mathrm{N}$ number of product variety which retailers have to manage in order to retain their old customer and target new customer (Lee and Kleiner, 2001). Reason being customer loyalty is eroding day by day (Motorola, 2009). Competition is at its peak and there is rising threat from foreign players (Ahya, 2006; KPMG report, 2009; Sukhadeve Biyani, 2011) Competition environment subjects retailers to risk on one side and on the other side it gives the ability to the retailers to increase the sales growth, provide attractive merchandise to the customer at required price and maintain profitability. Retailers are striving to improve service levels in terms of availability and variety and it is becoming imperative for them to introduce their own private labels (Haxthause, 2008).

According the Mpwanya (2005) "Availability is the capacity to have inventory when desired by the customer". Product availability is a key element of customer satisfaction and it is maintained by effectively managing the inventory. Through research it has been found that one of the important factors for achieving sales growth is ensuring availability of product within easy reach of consumer and merchandising the product at large number of outlets (Krishna, 2001). According to Wilson, Kingdom \& Reeve (1995) Merchandise availability is important determinant of effective inventory management. To make product available retailers need to focus on inventory accuracy (Awbi, 2006). Managing the availability of products at lowest possible cost is important for retailers (Gill, Soma \& Sutherland, 1985).
Optimum level of inventory has to be maintained in order to upgrade sales channel service level (Anand\&Cunnane, 2009) and to make product available of different variety. Retailer has to ensure the inventory of all type should be maintained and the reorder level and the level of stock outs should be set (Ghani, 1996).

According to Marco (1981) there was shift from cost based management to customer service, for that Retailers should understand customer needs, vendor partnerships, technology, data integrity, and performance measurements (Lee and Kleiner, 2001) and should have plans to deal with out of stock condition (Bleda, 2005). One of the important strategic tools that firms use to attract the customers, respond to the competition and improve their performance is product variety (Ren, hu, Lausman, 2008). Baumol \& Ide (1956) captured the trade off by pointing out that greater variety makes store more attractive to customer on the other hand it becomes difficult for the retailers in managing the items in the store. The consumers are peculiar about choosing the different style of products (Watson, 2009). On the other hand product variety increases inventory level, as more stock keeping units are required (Dubelaar, Chow \& Larson, 2001). Hence retailers optimize their inventory levels each product (Ton \& Raman, 2004).

As per Baumol \& Ide (1962) sales and inventory levels share positive relationship. According to Wolfe (1968), sales are affected by the amount of inventory displayed. Improper management of inventory can lead to reduced sales or loss of sales also which in turn results in failure of the business (Lalonde \& Zinser, 1976). Sudden decrease in sale could lead to obsolete inventory. Researchers contributed that inventory is positively correlated to sales and is sensitive to sales ratio. When the sales are low retailers reduce their stock and amount of inventory reorder. This enhances cash flow and makes product items manageable Zheng(2005). And increase in sales leads to decrease in inventory as more items are leaving the store than entering the store. In case of improper management of inventory, sales get affected creating losses for companies operating in highly competitive industry (Adeyeni, Salami, 2010).

According to Silver et.al. (1998) inventory turnover ratio is also a determinant of efficient inventory management. According to Zheng(2005) rate of inventory turnover provides a measurement to assist business enterprise in reducing its inventory to more manageable level. High turnover rate implies whole inventory sold more times per year this reduces investment in increase profit. According to Chen et.al., (2005) inventory turnover ratio of retail firms after the year 1995 started to improve as the firms laid more attention in their inventory management.

True demand of products is based on actual point of sale data not on forecast or historical sales data. Demand is volatile in nature it changes with change in season, fashion etc. Retailers have to project the customer demand for future purpose (Tao, 2006) which is quiet uncertain and it becomes difficult for retailers to project the demand (Kokemuller, 2013). 
The annual sales of the firm in the previous year is termed as retailer size and is positively related with Inventory turnover (Gaur, Kesavan, 2007). According to Kumar, Rajan \&Zingales (2012) retailer size is a measure where organizational boundaries are set.

Table 1: Determinants of Inventory Levels

\begin{tabular}{|l|l|l|l|}
\hline S.No & Determinants & Authors, year \\
\hline 1 & $\begin{array}{l}\text { Service } \\
\text { levels }\end{array}$ & Variety & $\begin{array}{l}\text { Gale, 2007; Chron , 2011; Battles , 2012; Ray , } \\
2012\end{array}$ \\
\hline & \multicolumn{2}{|l|}{ Availability } & $\begin{array}{l}\text { Lieberman, Helper, Demeester, 1996; } \\
\text { Bowersox et.al., 2008; Olivars, 2009 }\end{array}$ \\
\hline 2 & Sales Level & Smith, 1964; Patsula, 2001; Ray, 2012 \\
\hline 3 & Competitive Environment & Olivars, 2009 \\
\hline 4 & Demand uncertainty & Lieberman, Helper, Demeester, 1996; \\
\hline 5 & Inventory turnover & $\begin{array}{l}\text { Lovell, 1964; Guasch, Kogan, 2001; Lieberman, } \\
\text { Helper, Demeester, 1996 }\end{array}$ \\
\hline 6 & Retailers size & $\begin{array}{l}\text { Patsula, 2001 Lovell, 1964, Lieberman, Helper, } \\
\text { Demeester, 1996 }\end{array}$ \\
\hline 7 & Supplier Relationship & Patsula, 2001, Battles, 2012 \\
\hline
\end{tabular}

Effective Inventory management ensures reduction in cost, availability of material, required quality. Retailers need to embrace inventory management techniques to improve their competitiveness (Rajeev, 2008).

Every part of business is affected by Inventory Management process, it increases customer service, fulfil uncertain demands and ensure that customer return back to the retailers(Lockard, 2011). It ensures timely delivery of product, quality of post sales support and also affects efficiency of warehouse or store operation which impacts profitability and cash flow (Blackman, 2013). Inventory balance helps to figure out how much inventory is required, high inventory turnover ratio ensures product are not spoiled and become obsolete

\section{METHODOLOGY}

The study aims to identify the determinants of effective Inventory management in Consumer durable market and in order to develop the questionnaire and to find the determinants; a detailed literature review was done. Seventeen items were identified from literature review which has an influence on effective inventory management in retail. The study also attempted to identify the nature of relationship between determinants of Inventory management and Effective inventory management, the following hypothesis was drawn to address the issue:

$\mathrm{H}_{0}$ : Determinants of Inventory Levels do not have a direct relationship with Effective Inventory Management.

$\mathrm{H}_{1}$ : Determinants of Inventory Levels have a direct relationship with Effective Inventory Management.

Exploratory research design was adopted to identify the determinants of effective inventory management in consumer durable retail. Based on structured questionnaire, convenience sampling method was used to collect data. The data was collected from 60 organized and semi- organized retailers from New Delhi, Lucknow and Allahabad region. For the purpose of survey Semi-organized retailers are defined as "Family owned business but are registered for various taxes and are upgraded with the required technology using management functions to operate business". Organized retailers are those who have acquired licenses and are involved in trading activities have registered for income tax, sales tax etc. Organized retailers are the hypermarkets, retail chains, and privately-owned large retail businesses. Structured questionnaire was adopted to find the factor affecting effective inventory management. Questionnaire consisted of two parts, one was Retailers profile which was not mandatory for the retailers to fill and second part consisted of statements related to inventory management. The response were taken on five point likert scale with response varying on the scale of 1 for strongly agree \& 5 for strongly disagree.

SPSS(11.5) was used to analyze the data and Principal Component Analysis was done to identify the factors affecting inventory management. Barlett's test of sphercity and KaiserMeyer-Olkin (KMO) measure the sampling adequacy and the appropriateness of factor analysis. The derived factors were considered as independent variables to further test their relationship with dependent variable (Effective Inventory Management) with the help of regression analysis.

\section{FINDINGS AND ANALYSIS}

Survey shows that $40 \%$ retailers of consumer durable place their order on fortnightly and $30 \%$ on monthly basis. Products for display in retail store vary with parameters such as change in season like in summers Air conditioners and Refrigerators and in winters Washing machine and Microwave are given more weightage.

The overall KMO statistic for the study was 0.649 which indicated that the sample size was adequate for proceeding with PCA (MacCallum et. al., 1999; Tabachnick and Fidell, 2007; Field, 2009). The initial analysis extracted five factors with initial eigen values of above 1 (Kaiser, 1960) with a cumulative variance of $57.08 \%$ in data before rotation. The factor structure derived after rotation shows significant factor loadings ( $>0.5$ ) for each item and no significant cross loadings were found.

The factors extracted by PCA were for reliability. Hair et.al. (2010) defined reliability as an "assessment of degree of consistency between multiple measurements of variable". Table 2 shows the measure of the description statistics and cronbach's alpha score for constructs. Alpha values are exceeding the acceptable value 0.5 as suggested. Based on the values, the measure representing the factors may well be accepted and admissible.

The Cronbach's $\alpha$ value for factor 5(0.078) i.e. 'Competitive Environment' was below the acceptable level and was excluded from further study. Finally, the items that converge on factor 1 represent components of 'Retailer size', factor 2 represents 'Supplier Relationship' factor 3 represents 'Service level' and factor 4 represents 'Demand Uncertainty' 
Table 2: Final EFA and Reliability Analysis for Effective Inventory Management

\begin{tabular}{|c|c|c|c|c|}
\hline Factor Name & Items & Variance Explained & Factor Loading & Cronbach's Alpha \\
\hline \multirow{4}{*}{ Retailer size } & Store size & \multirow[t]{4}{*}{18.374} & .857 & \multirow[t]{4}{*}{0.8481} \\
\hline & Warehouse size & & .849 & \\
\hline & Backstore size & & .805 & \\
\hline & Obsolescence of product & & .735 & \\
\hline \multirow{5}{*}{ Supplier Relationship } & Inventory turnover & \multirow[t]{5}{*}{13.600} & .708 & \multirow[t]{5}{*}{0.6954} \\
\hline & New product launch & & .684 & \\
\hline & Information exchange & & .637 & \\
\hline & Supplier relation & & .607 & \\
\hline & Reorder time & & .561 & \\
\hline \multirow[t]{4}{*}{ Service level } & Product variety & \multirow[t]{4}{*}{13.024} & .738 & \multirow[t]{4}{*}{0.6625} \\
\hline & Stock keeping unit & & .611 & \\
\hline & Due to competition retailers adopt CRM & & .605 & \\
\hline & Product availability & & .540 & \\
\hline \multirow[t]{3}{*}{ Demand Uncertainty } & Demand & \multirow[t]{3}{*}{12.05} & .656 & \multirow{3}{*}{0.649} \\
\hline & Number of units sold & & .632 & \\
\hline & Reorder time & & .590 & \\
\hline \multirow[t]{3}{*}{ Competitive Environment } & Competition led to store renovation & \multirow[t]{3}{*}{11.054} & .643 & \multirow[t]{3}{*}{0.078} \\
\hline & Change in season & & .615 & \\
\hline & Competition & & .606 & \\
\hline
\end{tabular}

Table 3: Model Summary of Regression Analysis

\begin{tabular}{|l|l|l|l|l|}
\hline Model & R square & Adjusted $R$ square & Sig F change & Durbin Watson \\
\hline 1 & .319 & .24 & .003 & 1.9 \\
\hline
\end{tabular}

Table 4: Coefficients

\begin{tabular}{|c|c|c|c|c|c|c|c|c|}
\hline \multirow[t]{2}{*}{ Model } & & \multicolumn{2}{|c|}{ Un standardized Coefficients } & \multirow{2}{*}{$\begin{array}{l}\text { Standardized Coefficients } \\
\text { Beta }\end{array}$} & \multirow[t]{2}{*}{$T$} & \multirow[t]{2}{*}{ Sig. } & \multicolumn{2}{|c|}{ Collinearity Statistics } \\
\hline & & $B$ & Std. Error & & & & Tolerance & VIF \\
\hline 1 & (Constant) & .948 & .267 & & 3.553 & .001 & & \\
\hline & Demand uncertainty & .288 & .121 & .336 & 2.367 & .022 & .675 & 1.482 \\
\hline & Service Level & .003 & .076 & .005 & .035 & .972 & .713 & 1.403 \\
\hline & Supplier relation & .265 & .160 & .324 & 2.897 & .034 & .713 & 1.402 \\
\hline & Retailer size & .082 & .041 & .263 & 1.991 & .049 & .781 & 1.280 \\
\hline
\end{tabular}

Table 3 shows result of linear regression model. To test the regression model the Independent variables (IV) Demand uncertainty, Service level, Supplier relation, Retailer size, and the Dependent variable (DV) Effective inventory management were entered. Statistical significance of the incremental change in Adjusted $\mathrm{R}^{2}$ is critical for selecting the model and interpretation (Cohen and Cohen, 1983; Shah and Shin, 2007). The value of Adjusted $\mathrm{R}^{2}$ for this model is (.24). The value of Durbin-Watson statistic in model is 1.9 is within the acceptable range of 1 to 3 .

Table 5: Regression Analysis for Hypothesis

\begin{tabular}{|l|l|c|l|l|}
\hline Hypothesis & Predictor/Independent variable & Direction of relationship & Dependent variable & Regression analysis for hypothesis \\
\hline$H_{I a}$ & Demand Uncertainty & $\rightarrow$ & & Supported \\
\cline { 1 - 2 } & Service Level & $\rightarrow$ & & Not Supported \\
\cline { 1 - 2 } & Supplier Relation & $\rightarrow$ & & Supported \\
\hline$H_{I d}$ & Retailer Size & $\rightarrow$ & \\
\hline
\end{tabular}

\section{MANAGERIAL IMPLICATION}

It becomes necessary for a consumer durable retailer to build a trade- off between the demand and supply of products and do continuous planning for layouts, storage, displays issuances and deliveries. As consumer durable products are bulky enough more emphasis is given to storage space in warehouse and shop floor. The survey reveals that store size is an important determinant of effective inventory management for consumer durables retailers. It is difficult for all retailers to keep bigger spaces for stores they may adopt to reverse logistics strategy to free their supply chain, finances and warehouse or shop floor space from any kind of obsolete
Linear relationships between the IVs and DV ensure their best representation in regression analysis (Hair et. al., 2011). For testing this assumption, the partial plot for each IV has been studied. As the residuals in the plots do not exhibit any non linear patterns, the assumption of linearity has been met (Field, 2009; Malhotra and Dash, 2011). Demand uncertainty $(\beta=.336 \& \mathrm{Sig}=.022)$, Retailer size $(\beta=.263 \& \mathrm{Sig}=.049)$ and Supplier Relationship $(\beta=.324 \& \mathrm{Sig}=.034)$ are the significant determinants of effective inventory management. products.

The analysis show significant relationship between supplier relationship and effective inventory management. With the entry of global and domestic retailers in the market, retailing has become complex. Other factors which lead to complexities are variety, and growing customer demands. Supplier relation and information sharing among supplier and retailers on real time basis has become critical. Consumer Durable retailers may adopt various technology and information technology related tools like Barcode scanners, Point of Sale, EDC machines, etc. in order to keep themselves connected with suppliers. 
The survey revealed that Demand Uncertainty has a direct relationship with effective inventory management. Due to intense competition and shrinking product life cycles, manufacturers are introducing new products to add more variety making it difficult for a retailer to accurately project consumer demand. Managing inventory of all the variety of products is a challenge for retailers and situations get complex due to uncertainty of demand and makes decision making difficult. In the presence of uncertain demand, retailers objective is to minimize the expected cost. In the planning process to tackle with demand uncertainty a consumer durable retailer should take temporal decision at three levels of strategic, tactical and operational in order to identify the optimal timing, location and extent of additional investment. Technology application will help to monitor sales over a period of time and can also help to track demands that vary from one period to another.

The consumer durable retailers have to maintain multitude of products and also ensure availability to offer expected Service Level. The retailer has to strike a right balance between offering variety and making it available. It is necessary for the retailer to decide whether to stock a narrow range of products with greater depth or just a general stock with larger width. These above studied factors will help the consumer durable retailers in better managing their inventory which in turn will be able to fulfil the demands of the customer in right time, right location and right price. Effective management of inventory will help them in tracking their stocks on real time basis which will help in time reduction and maintaining the required stock will reduce the cost involved in holding the inventory.

\section{FUTURE SCOPE FOR RESEARCH}

This study has a narrow and explorative approach, investigating the different determinants of effective inventory management. It would be interesting to conduct a more detailed study with big sample size and covering more cities in India. Future research could follow on direction to identify the variables which are acting as moderating or mediating between the dependent and independent variable. And factors like innovation, technology can be explored to identify their mediating or moderating effects on inventory management.

\section{REFERENCES}

[1] Advisen, Electronics Retail, 2012 .

[2] A.Ayad, "Optimizing inventory and store results in a big box retail enviornment".International Journal of Retail\&Distribution Management, 36 (3), Pp:180-191, 2008.

[3] A. Bajaj, (n.d.). Bazee.com .

[4] Business Monitor International. (2012)\& India Retail Report Q1 2013. London: Business Monitor International Ltd.

[5] CB Richard Ellis, "MarketView India Retail", CBRE South Asia Pvt. Ltd, 2012.

[6] CGI., "Effectively Managing the Evolving Retail Ecosystem", CGI group Inc, 2004.

[7] R.Dalwadi, Rathod H.S.\& Patel A., "Key Retail Store Attributes Determining Consumers Perceptions: An Empirical Study of Consumers of Retail Stores Located in Ahmadabad (Gujarat)", SIES Journal of Management, Vol:7( 1), Pp:20-34, 2012.

[8] Deloitte, "Indian Retail Market-Embracing A New Trajectory", Deliotte Touche Tohmatsu India Pvt. Ltd, 2011.
[9] C.E. Gnanasambandam, "Online and upcoming: The Internet's impact on India”, Mckinsey, 2012.

[10] Hair, J. F., Jr., Black, W. C., Babin, B. J., Anderson, R. E., and Tatham, R. L. (2011). Multivariate Data Analysis (6th ed., p. 923). New Delhi: Dorling Kindersley (Licensees of Pearson Education Inc.).

[11] G.Ian, "The changing face of Retail", Deloitte, 2011.

[12] Ibs, "Vertical industry brief Consumer durable", ibs, 2005.

[13] A. Kearney, Glabal Retail Expansion: Keeps on Moving - 2012 Global Retail Development Index. Korea: ATKearney, 2012.

[14] P. Kotler, "Marketing Management", Prentice Hall of India Private Limited, New Delhi, 2006.

[15] KPMG, "The Evolution of Retailing", KPMG, 2009.

[16] J.L.Lasalle, "Retail Realty in India: Evolution and Potential", PWC, 2014.

[17] H.H.Lee, B.H.Kleiner,"Inventory Management In The Women's Retailcl Othing Industry", Management Research News , 24 (3), 2001.

[18] M.W.Levy, "Retailing Management", New York:Tata McGraw Hills, 2007.

[19] R.C. MacCallum, L.R. Tucker, "Representing sources of error in the common factor model: Implications for theory and practice", Psychological Bulletin,109, Pp:502-511,1991.

[20] Pricewaterhouse Coopers; FICCI., "The Indian Kaleidoscope: Emerging trends in Retail”, India: Pricewaterhouse Coopers (PWC), 2012.

[21] PricewaterhouseCoopers, "Winning in India's Retail Sector: Factors for Success", India: PricewaterhouseCoopers (PwC), 2011.

[22] V.K. Rao, "S.W.O.T. Analysis of Retail Industry With Reference To Various Segments of Retail Enterprises In Visakhapatnam, Andhra Pradesh, India", International Journal of Retailing \& Rural Business Perspectives, 2 (1), 2013.

[23] S.Shah, "The rise of the affluent Asian shopper", PWC, 2013.

[24] E.P.Silver, "Inventory Management and Prouction Planning and Scheduling", 3 ed. Wiley, NewYork, 1998.

[25] H.Singh, "Retail Management A global perspective (revised ed.)", New Delhi: S chand, 2011.

[26] H. Singh,S.R.Srinivasan, "Mall Management: Operating in Indian Retail Space", New Delhi: Tata McGraw Hill,2012.

[27] P. Singh, D.Sharma, "Foreign Direct Investment Vs. Indian Retail Industry", Radix International Journal Of Economics \& Business Management ,2 (2), 2013.

[28] P. Sudame, B.Shivathanu, "Challenges Affecting The Organized Retail Sector",Arth Prabhand: A Journal of Economics and Management, 2013.

[29] TCS, "SKU Rationalization A Technique for Inventory Optimization in the Retail sector", 2012.

[30] B.G.Tabachnick, and L.S.Fidell, "Using Multivariate Statistics. Allyn and Bacon: Boston", Mass, 2011.

[31] B.L.Wilson, M.Kingdon and T.Reeve, "Best practices in retailing: quick hits in store level merchandise and inventory management", Chain Store Age, November, Pp.100, 1995.

[32] The Indian Retail Sector Report. Michaelpage, 2013.

[33] A.Yusuf, "Determinants of Inventory Managements as a Component of Working Capital in Ensuring Corporate Profitability-A Conceptual", Research Journal of Finance and Accounting , 3 (11), 2012.

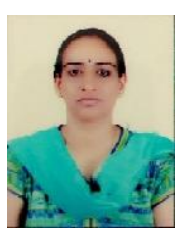

Dr. Vibhuti Tripathi has over 5 years of industry experience in sales and retail operations, and over 9 years of teaching experience. With her core competence in Marketing and allied subject, Dr. Tripathi has earned her $\mathrm{Ph} . \mathrm{D}$. in the area of retail management from Motilal Nehru National Institute of Technology, Allahabad and has been teaching a variety of courses, Marketing Management, Business Environment and Retail Management. She has 17 years papers to her credit in national and international journals. Her research interest includes Retail Management, Consumer behavior and Brand Management.

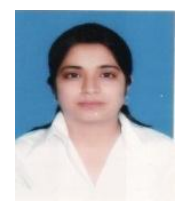

Priyanka Kochhar earned her Undergraduate degree in Industrial \& Production Engineering in 2007 from Institute of Engineering and Rural Technology Allahabad, Master of Business Administration specialised in Operations Management in 2010 from Indian Institute of Information Technology Allahabad and submitted PhD in Merchandise Management from Motilal Nehru National Institute of Technology, Allahabad. She has over 7 years of teaching experience and has been teaching a variety of courses Operations Management, Supply Chain Management, Principles of Management. She has 08 papers to her credit in various national journals and National and International Conferences. 